\title{
DEATH: THE ULTIMATE TRANSFORMATIVE EXPERIENCE ${ }^{1}$
}

\author{
Evan Thompson
}

[Forthcoming in a volume on transformative experience edited by Enoch Lambert and

John Schwenkler for Oxford University Press]

\begin{abstract}
Death is the ultimate transformative experience. "Death" here means not the state of being dead but rather the whole process of dying, culminating in the end of a person's life. Death is "epistemically transformative" because you cannot know what it is like to die until you experience dying and this experience can enable you to understand things in a new way. Death is "personally transformative" because it changes how you experience yourself in ways that you cannot fully grasp before these changes happen. At the same time, death is unlike any other transformative experience. It is final, all encompassing, and has fundamental significance. Its power to reveal new truths about your self and your life is exceptional. It offers prospective and retrospective perspectives that differ from those of any other experience. This chapter examines death by describing its unique characteristics as the ultimate transformative experience. The practical benefit of this perspective is to suggest new philosophical resources for physicians, hospice workers, policy makers, and family members who care for dying loved ones.

Death is the ultimate transformative experience. ${ }^{2}$ I do not mean the state of being dead, in which the person has ceased to exist and we suppose there to be no possibility of experience for that person. I mean the whole process of dying, culminating in the end of a person's life. ${ }^{3}$ So understood, death is "epistemically transformative," because you cannot know what it is like to die until you experience dying and this experience can enable you to understand things in a new way. ${ }^{4}$ Death is also "personally transformative," because it changes how you experience yourself in ways that you cannot fully grasp before these changes happen. At the same time, death is unlike any other transformative experience. It is the ultimate one, not only in being final, inevitable, and all encompassing, but also in having fundamental significance. It is the kind of transformative experience against which or from which all other transformative experiences can be viewed. Death's power to reveal new truths about your self and your life is exceptional. Dying comprises prospective and retrospective perspectives that differ from those of any other experience. A consideration of death as the ultimate transformative experience brings an important perspective to the philosophy of death
\end{abstract}


while offering insights for physicians, nurses, hospice workers, and family members who care for dying loved ones.

My inspiration comes from a statement L. A. Paul makes in a footnote on page 111 of her book, Transformative Experience. She writes: "Your own death is the ultimate transformative experience, and as such, you are particularly ill-equipped to approach it rationally." Paul does not elaborate on this remark, but I propose to take two thoughts from what she writes in the context of the argument of her book.

First, death shares the characteristics that make transformative experiences as a whole pose a challenge to a standard (but culturally specific ${ }^{6}$ ) way of thinking about what it is to be rational and authentic. A transformative experience teaches you something you could not have learned without having that kind of experience, and it changes your desires, preferences, and understanding of your self. In Paul's view, the challenge to rational authenticity arises in situations of transformative choice, in which you must decide whether to undergo a transformative experience. (Two of her examples are whether to become a parent and whether to receive a cochlear implant if you have been deaf from birth.) Authenticity requires that you choose based on your own ability to imagine what the new experience will be like for you and the value you place on having that kind of experience. Rationality requires that you forecast the likely outcomes of your choice, including what the resulting new experiences will be like for you, that you assess the outcomes according to your own first-personal and "subjective values,"7 and that you match your decision to your preferences (to what you prefer to happen as a result of your choice, given your subjective values). The problem is that it seems that you cannot adequately imagine what the experience will be like before you undergo it, and that you cannot determine what value the experience will have for you, because the experience may change your values and hence your preferences. Death - the whole transformative experience of dying - seems to pose the same kind of problem: How are you supposed to be able to imagine it before you undergo it, and how are you supposed to know how it may change your values and your preferences, or more generally, your sense of what is personally meaningful?

Nevertheless - and this is the second thought I take from Paul's remark-death is not just another kind of transformative experience. It is, as she says, the ultimate one. 
Although you can choose to end your own life, most of us do not choose our own deaths and you cannot choose not to die. ${ }^{8}$ In the case of every other transformative experience, you focus on what you will be like after the experience, whereas in the case of death, the problem is how to approach it, given our limited knowledge of what it is like. Its inevitability and finality, and the dissolution it entails, are especially hard to grasp from within. ${ }^{9}$ The barrier that death throws up to the imagination is of an entirely different order of difficulty from that of any other transformative experience. The affective response and the immediate engagement of the emotions that the real or imagined prospect of death elicits are unlike those elicited by the prospect of any other transformative experience. For these reasons, if you are generally ill-equipped to approach transformative experiences rationally, you are particularly ill-equipped to approach death rationally.

These thoughts set the context for this chapter. I wish to examine the unique characteristics of the ultimate transformative experience of death. My main motivation is to bring philosophy to bear on the experience of death in hospice (including home hospice care). My conviction is that the current philosophical concern with transformative experience, which Paul's book, Transformative Experience, has sparked, can help to reawaken a guiding impulse of ancient philosophy, namely, to prepare one's mind for death, whenever it may come, and to live one's life accordingly. ${ }^{10}$ The hospice is a crucible for facing death. I wish to bring the hospice movement and philosophy together to learn from and invigorate each other. This aim sets the context and scope of much of my discussion. It is the reason that I focus mainly on the experience of dying from a terminal illness or from senescence in the modern Western hospice setting.

Nevertheless, I do not mean to imply that dying in hospice can serve as a model for understanding every kind of death. Indeed, one might wonder whether there is any such thing as "the experience of death." One might even ask, to what extent can we talk about "the experience of death" in general terms as an identifiable category of human experience about which we can make useful generalizations? ${ }^{11}$

From the perspective of the hospice movement, it has been very important to talk about death in this way in order to develop better models of how to care for dying people. From a broader perspective, however, I would submit that the sense in which there may 
be no such thing as "the experience of death" is the sense in which there may be no such thing as "the experience of love" or "the experience of grief." There are many ways to experience death or love or grief. Nevertheless, in each case there remains an identifiable category of human experience about which we can make useful generalizations, as long as we recognize that there are many subcategories and that our generalizations must take into account the social, cultural, and historical settings of the experience, including how those settings can be constitutive of the experience. We also need to recognize what Ian Hacking calls "looping effects," whereby the categories that we use to classify people and their experiences change people and their experiences, especially in medical contexts. ${ }^{12}$ We must also not lose sight of the ineliminable individual variability of experience. More to the point philosophically, our conception of experience must be a "thick" or "wide" conception that includes the way the world is as part of the experience.

This chapter is part of a larger project that includes reflecting on what it might mean to be better or worse equipped to approach death rationally and authentically. That project includes an examination of whether you can imagine what it is like to die. I believe that you may be able to do so in certain respects and that this fact has important implications for our understanding of transformative experiences. You need to rely on a range of first-person and second-person information, including second-person testimony from the dying (including "moral testimony" about the values of experiences ${ }^{13}$ ), your own experiences of caring for the dying, contemplative practices, and "thick" imagination, that is, imagination that engages your emotions and targets not just the qualities of experience from within but also the way the world is beyond your individual self. ${ }^{14}$ Literature is an especially important source for this kind of rich imagination. Consider Tolstoy's The Death of Ivan Ilyich or Herman Broch's The Death of Virgil or the Japanese tradition of jisei (the death poem). I also believe that being well-equipped to approach death rationally and authentically requires caring for the dying, and that our society is particularly ill-equipped to approach death rationally and authentically because caring for the dying is not a part of normal life. ${ }^{15}$ As physician Haider Warraich writes in his recent and important book, Modern Death, "At no time in our history has death been farther from home than in the last few decades." "Finally, I believe that whether an experience is transformative can depend causally and constitutively on matters of social 
justice. ${ }^{17}$ Social conditions can make the transformative experience of death more or less harmful. These social conditions include not only whether one has access to proper endof-life care but also the pervasive medicalization of death. As Warraich notes, "contrary to general perception, never has death been as feared as it is today. The more medicalized death gets, the longer people are debilitated before the end, the more cloistered those who die become, the more terrifying death gets." 18 Thus, issues about social justice are inseparable from issues about how we are to be able to approach death authentically and rationally. This chapter, which focuses mainly on certain unique characteristics of the ultimate transformative experience of death, is a prelude to that larger project.

\section{DEFINING DEATH}

Many events make up the dying process. Which one counts as death depends on how we conceptualize or define death, and on the medical standards or criteria we use to determine when death has occurred. ${ }^{19}$

One event is the point at which dying is irreversible and death is assured. Stephen Luper calls this event "threshold death." "20 It has been conceptualized in different ways, either as the irreversible cessation of the integrated functioning of the organism ("integration death" ${ }^{21}$ ), as the irreversible loss of consciousness, or as the irreversible loss of personhood. Different medical standards or criteria have been proposed in order to determine when death occurs, according to one or another of these conceptions. The main standards that have been debated are the irreversible cessation of circulatory-respiratory function, the irreversible cessation of the functioning of the entire brain (including the brain stem), and the irreversible cessation of the functioning of the cerebral cortex. ${ }^{22}$

Another event is the ending of the dying process, which Luper calls "dénouement death." ${ }^{23}$ Neurologist Steven Laureys describes that event as "the discontinuous event... that separates the continuous process of dying from the subsequent disintegration." ${ }^{24}$ It defines death in the restrictive sense of life's termination point.

These conceptualizations and definitions of death, as well as the medical standards for determining when death occurs, are based on analyzing death from the outside, in third-person terms, not from the inside, in first-person terms. By themselves they tell us little about the experience of death. 
Nevertheless, threshold death and dénouement death, as well as many other phases of dying, can be subjectively experienced, especially in the contemporary hospice setting and as a result of modern methods for resuscitation. ${ }^{25}$ Medical sociologist Allan Kellehear writes in his book, The Inner Life of the Dying Person, that "studies suggest and describe transformative psychological, social, and spiritual experiences that occur, for some people at least, even into the first few minutes after a medical judgment of death has been pronounced." 26

Two points deserve emphasis here. First, notice that Kellehear is talking about medical judgements, which are fallible. Judging that a person is dead is one thing; the person's actually being dead is another thing. Second, the transition from being alive to being dead can be indeterminate. Consider these words from a nurse's blog: "The first thing I learned was that alive/dead is not the easy dichotomy that you would think it is. Either you're dead or not. But I go uncommonly religious and tell people that the Bible says it's 'the hour of our death' for a reason. In the ER, I saw one person during my entire time there be pronounced and then sit up and pull her tube out. Now I know to give it a while before pronouncing. ${ }^{27}$

The grey zone between life and death is not necessarily a sign of a lack of scientific knowledge; on the contrary, it reflects modern medical advances and is characteristic of "modern death." In Warraich's words: "Not only have biomedical advances changed the ecology, epidemiology, and economics of death, but the very ethos of death-in the most abstract possible sense - has changed. Far from being clearer, the line between life and death has become far more blurry. These days we can't even be sure if someone is alive or dead without getting a battery of tests." 28

Nevertheless, we do lack knowledge about one crucial matter, namely, about exactly how the brain supports consciousness and whether it is possible for certain kinds of conscious awareness to remain present for some time after the heart stops beating and breathing ceases. For example, a study in rats showed that complex dynamical patterns of brain activity can continue for up to 30 seconds after cardiac arrest, ${ }^{29}$ and a recent study in humans found that brain activity apparently continued in one patient up to 10 minutes after the heart stopped beating. ${ }^{30}$ Consider also the state of very deep coma, which is considered to be the turning point between a living brain and a dead brain. The isoelectric 
(flatline) EEG that characterizes this state is one of the criteria used to assess brain death. A recent study found that brain activity is generated in the hippocampal formation (a structure crucial for memory and spatial cognition) and transmitted to the cortex during very deep coma in humans and cats, and that this brain phenomenon is deeper than the one reflected by the isoelectric EEG. ${ }^{31}$

The Kellehear passage I quoted earlier occurs in the context of his considering the related cases of patients who have been revived from coma or resuscitated after cardiac arrest and who report conscious experiences of thought and feeling that seem to them to have occurred while they were in these states. Kellehear describes these cases of "neardeath experiences" as ones in which the patients "are actually aware of their own death." 32 But caution is needed here. First, the patients did not die (and accordingly we call their experiences "near-death experiences," not "death experiences"). Second, it is not clear that these experiences happen at the precise time that the EEG is isoelectric rather than just before the flatline state or just after this state when the patients are recovering. ${ }^{33}$

In addition, we need to distinguish between being dead as a reversible medical condition and being dead as an absolute irreversible condition. Death in the medically reversible sense is equivalent to the cessation of blood flow, respiration, brain-stem activity, and whole brain function. As a result of advances in resuscitation science, it has become possible "to reverse death [in this sense], not only in the immediate postmortem period but also potentially for relatively prolonged periods of time after it has occurred." 34 The reason for this possibility is that "human cells do not become irreversibly damaged or die immediately postmortem." 35 Thus, death as an absolute irreversible condition occurs only when cell death becomes permanent.

These considerations about the fallibility of medical judgements of death and the grey zone between being alive and being dead concern the difficulty of saying exactly when the end of dying happens and the state of being dead ensues. There is a corresponding difficulty about saying exactly when dying begins. Saying that dying begins when death is inevitable has obvious problems. On the one hand, death is inevitable once life begins. From this perspective, the process of living is the same as the process of dying. On the other hand, in certain cases of critical injury or illness, imminent 
death may seem inevitable, but the patient recovers, or imminent death may not seem inevitable (the patient has a good chance of recovery), but nonetheless the patient dies.

The hospice setting is relevant here. Hospice workers often use the terms the "preactive phase of dying" and the "active phase of dying." ${ }^{36}$ The pre-active phase usually lasts on average a few weeks, and the active phase lasts on average a few days. These phases have characteristic physical and psychological signs and symptoms, though there is a large amount of individual variability.

Given all these considerations, I am defining "death" as the whole process of dying, especially "active dying," including — but not limited to — its end point and the ensuing state of being dead.

I mean for this definition to be neutral on the question of the survival of consciousness after death. In particular, I do not wish to build into the definition of death an entailment to the metaphysical thesis of annihilationism. In other words, I would like the definition to be consistent with the possibility of some kind of continuance of the mind or consciousness after death, despite whatever doubts I may have about such continuance actually being the case. Whether experience in some sense is possible after absolute irreversible death is just the issue of the survival of consciousness after death, which I do not think the definition of death should prejudge. Whether experience in some form is possible during or after reversible medical death is the question raised by neardeath experiences. I take this question to be open, given our limited knowledge of the brain and how it supports consciousness. Nevertheless, I think that the evidence to date from the study of near-death experiences does not give us reason to think that consciousness continues after death. ${ }^{37}$

In summary, the point of defining "death" as the whole process of dying is to accommodate the experiential side of active dying and its culmination in the state of being dead. In contrast, philosophical discussions that follow the Epicurean definition of death as the state of dissolution or annihilation, ${ }^{38}$ or that define death simply as the absence of consciousness and life, ${ }^{39}$ are too restrictive. They elide the dying experience and fail to include the dying person's inner life. We can remedy this shortcoming by bringing the concept of transformative experience to bear on our thinking about death. By 
describing death as the ultimate transformative experience we can reinstate the firstperson perspective in the philosophy of death.

\section{THE TRANSFORMATIVE EXPERIENCE OF DYING}

Death is epistemically transformative because it teaches you things you cannot learn until you undergo it, and it is personally transformative because it deeply changes how you experience your self. These facts are well documented by those who care for the dying and listen to what they have to say. ${ }^{40}$

A recent study in the Netherlands examined how cancer patients react to the realization that their death may be imminent. ${ }^{41}$ The realization provokes great distress, leading to what the authors of the study call an "existential crisis" with any or all of the following seven characteristics: (1) an acute awareness of one's own finitude; (2) a limited sense of the future, including a feeling that what remains of the future is threatening and alarming; (3) a loss of meaning, especially for the sense of purpose in one's life; (4) fear, anxiety, panic, and despair; (5) extreme loneliness, even when surrounded by love and care; (6) powerlessness; and (7) an identity crisis, aggravated especially by physical mutilation and dependence on others.

Philosopher Ken Chung, a month before he died at the age of 39, published a blog essay, “Is Dying a Transformative Experience?", in which he reflects on Paul's conception of transformative experience in the light of his own experience of having Stage IV pancreatic cancer. ${ }^{42}$ In his words:

So what tells me I'm dying? There's no gut feeling - no gut knowledge that I only have so much time. There's just my doctors' words buttressed by data that only they can intelligibly interpret... But there is something to knowing that you have a disease that's going to kill you soon. If you accept that fact, and acknowledge it deep down and in all the things you do, I think it does transform you... [T] who are not. If you are young, you still want to do things that can shape the rest of your life. If you are older or if you are sick like me, you might not care so much to shape the rest of your life as much as to live it and appreciate what you can. These differences between us are unavoidable and understandable. But it means that no matter how much some of you are there 
for me, I still feel alone. You do not know what it's like to be dying, and you probably can't know, until it happens to you. ${ }^{43}$

Chung's description and the study of the cancer patients mentioned above bring into relief how the transformative experience of terminal illness and dying (in modern Western societies) differs from other kinds of transformative experience. ${ }^{44}$ In illness and dying, one's future appears highly contracted and one feels alone and often powerless. Compare this sense of a shrunken future and the feeling of a loss of control with the sense of an open future and a feeling of agency in the typical (affluent, Western) transformative experience of becoming a parent, especially as this experience is described in modelling the problem of transformative choice. ${ }^{45}$ This problem is presented as one in which you have to choose between two open-ended, possible futures before you-whether to become a parent or to remain childfree - and as one in which you have control over which scenario to bring about. In the experience of dying, however, this sense of an open future vanishes along with the feeling of control. The transformative experience of dying thus calls into question precisely the sense of self that has been used to pose the problem of transformative choice, namely, the experience of the self as a rational, autonomous agent in control of its life and its future.

We can draw a general lesson from this point. Not only are many experiences transformative without being the result of choice, but also that an experience is not the result of choice can be part of what makes it transformative.

Let me connect these observations to an ancient philosophical idea. As Amber Carpenter writes in her paper, "Metaphysical Suffering, Metaphysics as Therapy," Greek grammar contains "an insight into the human condition." 46

In an irregular formation of the passive voice, paschein, 'to suffer', is the ordinary passive form of poiein, 'to do'. To suffer is to have something done to one, or happen to one. It is particularly defined through its contrast class: doing, being active, and especially contrasted with being in control. Lack of control is suffering. ${ }^{47}$

I take the insight here to be that suffering implies enduring or undergoing something you cannot control, but I do not think it is correct to state that lack of control per se is suffering. After all, many situations in which you lack control can, under the 
right circumstances, be experienced as joyful, thrilling, or liberating. Rather, it is the experience of wanting and trying to be in control and not being able to be in control that is suffering.

Trauma is a case in point, and one that has important connections to the experience of dying. Susan Brison, in her powerful book, Aftermath: Violence and the Remaking of a Self, in which she reflects philosophically on her own experience of being sexually assaulted and nearly murdered, writes, "One of the most serious harms of trauma is that of loss of control." 48 She defines a traumatic event as "one in which a person feels utterly helpless in the face of a force that is perceived to be life-threatening." 49 She mentions "terror, loss of control, and intense fear of annihilation" as part of the immediate response to a traumatic event, and notes that the long-term effects "include the physiological responses of hypervigilance, heightened startle response, sleep disorders, and the more psychological, yet still involuntary, responses of depression, inability to concentrate, lack of interest in activities that used to give life meaning, and a sense of a foreshortened future." ${ }^{50}$ The loss of control occurs not just when the traumatic event happens but also long afterward. People who suffer from post-traumatic stress disorder (PTSD) experience intrusive and emotionally overwhelming memories, heightened startle responses, and involuntary responses to things that previously provoked no response. "A trauma survivor suffers a loss of control not only over herself, but also over her environment, and this, in turn, can lead to a constriction of the boundaries of her will... Some reactions that were under the will's command become involuntary and some desires that were once motivating can no longer be felt, let alone acted upon."

Loss of control is one reason that trauma transforms the self: "Such loss of control over oneself can explain, to a large extent, what a survivor means in saying, 'I am no longer myself.",52 Part of what makes trauma a personally transformative experience is its resulting from an unwilled and unwanted loss of control.

In Brison's case, the transformative experience of trauma involved a transformative experience of dying in two ways. First, she was the object of an attempted murder and experienced coming very close to death. Second, she describes her life afterward as if she were "experiencing things posthumously." $" 53$ In her words: 
When the inconceivable happens, one starts to doubt even the most mundane, realistic perceptions. Perhaps I'm not really here, I thought, perhaps I did die in that ravine. The line between life and death, once so clear and sustaining, now seemed carelessly drawn and easily erased.

For the first several months after my attack, I led a spectral existence, not quite sure whether I had died and the world went on without me, or whether I was alive but in a totally alien world. ${ }^{54}$

Brison describes the experience of survival and recovery as one in which she had to let her former self die, making the trauma tantamount to a kind of death:

I am not the same person who set off, singing, on that sunny Fourth of July in the French countryside. I left her in a rocky creek bed at the bottom of a ravine. I had to in order to survive. ${ }^{55}$

Brison reports that, in order to recover, the trauma survivor needs to be able to take control of herself, and that one of the important ways this happens is by constructing a narrative and telling it to an empathetic listener. The narrative enables the survivor "not only to integrate the traumatic episode into a life with a before and an after, but also to gain control over the occurrence of intrusive memories." exercised, leads to greater control over the memories themselves, making them less intrusive and giving them the kind of meaning that enables them to be integrated into the rest of life." 57

As a general matter, in situations in which you want and try to be in control, but feel powerless to choose or to act, you experience suffering. Choosing and acting are rational activities, in the sense that they involve having and being able to give reasons, and being able to devise a meaningful narrative to make sense of what has happened or is happening to you and of what you do. So, engaging in meaningful activity, including constructing a narrative, can mitigate suffering.

Dying patients in hospice cite the loss of control, including the inability to preserve the meaningful narrative of a life with choice, action, and an open future, as one of the principal causes of their suffering. Loss of control and the breakdown of meaning make the suffering an existential crisis. Palliative care specialists describe this kind of suffering as "intrinsic to the dying process." ${ }^{, 58}$ Some specialists argue that it may not be possible to 
alleviate it and that it can be a mistake to try to relieve it. Rather, the palliative care provider should acknowledge it with the patient, an approach called "sitting with suffering." 59

Sitting with suffering, for both the dying and those who care for them, implies a different approach to the felt loss of control from that of trying to regain control. The approach is not to try to control or manage the existential crisis, as one tries to control or manage physical pain, but rather to bear witness to the suffering. Sitting with suffering suggests a meditative posture, one that recognizes and observes the reality of suffering, without trying to assert control where there is ultimately none to be had.

Brison, too, points out that in recovering from trauma, the effort to control your life through constructing a narrative can be taken too far and can hinder recovery, and that it is important to learn how to relinquish control and to let go. ${ }^{60}$ Similarly, the task of the empathetic listener is not to control but rather to bear witness.

This kind of letting go of control is very different from the kind of control you are supposed to be exercising in making a transformative choice by trying to bring the future into line with your subjective values and preferences. Indeed, part of the challenge that the transformative experience of death poses is precisely that you may feel a pressing need to find a way to let go of that sense of self as controller. Nevertheless, it is crucial to realize that letting go of control in this way can be rational. It can stem from an accurate perception of how things are, namely, transient and essentially out-of-control, and from an acceptance in which you exercise your capacity for understanding. Being capable of such perception and acceptance is thus part of what it is to be well-equipped to approach death rationally.

Dying individuals and those who care for them often report that practicing this kind of perception and acceptance precipitates a transformation of the self and the emergence of new meaningful narratives. They report that suffering is ameliorated through this process rather than through efforts at control. For example, in the cancer patients of the study mentioned earlier, losing the sense of self as a controlling agent initiated a phase of deep mourning, but the patients who were able to live through the intense mourning and let go of this sense of self unexpectedly experienced a deeper sense of self and belonging to a larger whole. One patient reported: "suddenly I heard the beating of my heart and I 
thought: yes, it is a piece of nature that is there. And then I felt myself being part of nature." ${ }^{, 61}$ This relinquishing of an "ego-centered worldview in favor of a deep sense of being embedded in a larger whole" ${ }^{, 2}$ lessened these patients' loneliness and fear of death.

I have called attention to the shrunken sense of the future in the transformative experience of death. The retrospective perspective too differs from that of any other kind of transformative experience. You know that your time is coming to an end and that you have a last opportunity to review your whole life. Review and reminiscence, which can be spontaneous or deliberate, figure prominently in the dying experience. ${ }^{63}$ In Kellehear's words:

Any major life crisis can bring you to a point where you will interrogate the "past selves" in search of a discovery or rediscovery of the meaning of self, but dying will often do this too for many people because dying is the final roundup of all meaning about their life. People review their lives for another reason, too. Sometimes, it is a simple reacquaintance with the contents of memory. ${ }^{64}$

Reacquaintance with the contents of memory is especially poignant in people suffering from dementia. They cherish memories as a critical way to hold onto their sense of self as it slips away. Kellehear quotes these words from Thomas DeBaggio's memoir of living with Alzheimer's disease: "Even in this time of failing memory, I am happy to stay closeted in my mind and bring up broken memories to paw over., ${ }^{, 65}$

Life review in the face of death occurs not just in the elderly but also in younger people and children. Kellehear describes three main forms the remembering takes. First, people can deliberately and selectively review important relationships and events. This kind of remembering serves self-understanding and anticipatory grieving for future loss. Second, people can experience an uncontrolled, nonselective, and panoramic life review, especially in traumatic situations. This kind of memory event is one of the elements used to classify near-death experiences. ${ }^{66}$ Third, people in prison or death camps remember and dwell on quotidian events of a better life, often in order to block out the terrible suffering of their present circumstances.

These kinds of remembering can retrospectively recast the meaning of earlier transformative choice points of your life, the meaning of the transformative decisions that 
you made, and the meaning of the transformative experiences that you had as a result. Imagine recalling at death your decision to become a parent, or to join the armed forces and go to war, or to abandon academic life and become a farmer, or to become a monk or a nun, or to renounce your monastic vows and return to secular life. Thus, another way that death is the ultimate transformative experience is that it can serve as an ultimate meta-perspective from which to assess the value and meaning of every other experience you have had, including especially those resulting from the transformative decisions of your life.

In his summary of how the experience of death is transformative, Kellehear distinguishes between the three phases of early dying, late dying, and the moment of death. Throughout the early and late dying phases, physical distress, mental suffering, and existential crisis mix with new insights and fresh perceptions. Early in the dying process,

people are already noticing the world is different for them. They see the world afresh; their perceptions are rejuvenated; they start to notice things they did not see before in their environment. These dying people's altered perceptions provide them a new appreciation of life and what it is offering them day to day. ${ }^{67}$

Gaining these new experiences is epistemically and personally transformative. They stem from the growing realization of your impending dissolution and deeply change how you experience your self. Kellehear states that the "most fundamental observation" about the dying experience is that “one leaves one's former self to become a new self or to integrate a new sense of self." ${ }^{, 68}$ The transformation reorganizes old values and preferences, and brings new ones. As dying progresses, such changes increase, so that people come to expect them:

$[\mathrm{M}]$ any dying people are themselves amazed at the how the world around them seems so different and how their inner life seems so in the throes of transformation that ever newer, more novel, ever strange, and foreign experiences seem not only to be possible but even very likely to them. Many dying people at the center of these new perceptions and changes come to expect more alterations to their inner realities and experiences. ${ }^{69}$ 
These alterations become pronounced in the late phase of dying and at the moment of death. Prolonged experiences of pain and distress can transition to feelings of peace, calm, and serenity. ${ }^{70}$ About one-third of dying people have deathbed visions, though their prevalence is lower in modern Western societies where opiates, which apparently suppress these visions, are routinely used in caring for the dying. Palliative care medicine is taking a new interest in deathbed visions and dreams as transformative experiences in their own right. ${ }^{71}$ They do not seem to be predicted by diagnosis, religion, ethnicity, class, gender, or age, and are generally described as positive. ${ }^{72}$ Hospice workers also report that dying people often confront and reconcile themselves to what they take to be deep truths about themselves revealed in their final moments, and that they discover new truths.

We can relate this idea of death as revelatory to Paul's concept of "revelation," which she uses as a way to deal with the problem of transformative choice. ${ }^{73}$ Recall that making a transformative choice requires you to imagine what the new transformative experience will be like and to determine the subjective value it will have for you, but you cannot do this before you have the experience, and therefore you lack the rational means to choose. Paul proposes that we reframe how we think about transformative choices by seeing them as presenting us with a choice between either embracing or avoiding what she calls "revelation." You can either choose to have the new experience for the sake of what it reveals to you, including new subjective values and the discovery of a new sense of self, or you can choose to forgo the revelation and affirm your current life.

In the case of death, however, you cannot choose not to undergo the transformation. What you may be able to choose, to some extent, is how you undergo it. You may be able to choose to meet the transformation and what it may reveal with acceptance instead of trying to push it away, or you may choose to resist and fight it until the very end. Understanding and being prepared for these choices and possibilities is also part of what it means to be well-equipped to approach death rationally.

Here, "rationally" means being able to exercise your capacities for observation, understanding, choice, and letting go. It does not mean the limited, decision-theoretic sense of instrumental rationality, which is the kind of rationality usually emphasized in the philosophical literature on transformative experience. Indeed, one of the benefits of 
reflecting on what it might mean to be better or worse equipped to approach death rationally is that such reflection can help us to see how limited the instrumental sense of rationality may be for our understanding of transformative experiences altogether.

\section{DEATH AS EXISTENTIALLY TRANSFORMATIVE}

Death is not just epistemically and personally transformative; it is existentially transformative. ${ }^{74}$ Death constitutes your finitude, and the knowledge that you will die and the transformative experience of dying reveal your finitude in a unique and all encompassing way.

Any transformative situation confronts you with your finitude - with your having to go down the path of one transformative course of action rather than another. As Sartre writes: "To be finite, in fact, is to choose oneself - that is, to make known to oneself what one is by projecting oneself toward one possibility to the exclusion of others." ${ }^{75}$ Sartre rejects what he sees as Heidegger's "strict identification of death and finitude." 76 Being immortal, in the sense of having an unending lifespan - as in the Makropolous case discussed by Bernard Williams ${ }^{77}$ or Paul's example of becoming a vampire ${ }^{78}$ — would not remove your finitude, for you would still find yourself confronted with bounded choices and courses of action, even if there were an endless series of them. Nevertheless, immortality would radically change your finitude, and this fact is enough to show that death constitutes your finitude, even if it is not strictly identical with it.

Following Heidegger, we can say that your death is not just your final and inevitable transformation, but also the one that fully individuates you and that ultimately no one can take away from you or stand in as a substitute for you. ${ }^{79}$ This existential characteristic of being "ownmost" enables you to take up a meta-perspective from which you can view any other of your possible transformations, including especially the actual transformative experiences of your life that you may revisit retrospectively when you are dying. Earlier I said that the transformative experience of death can retrospectively recast the meaning of prior experiences. I can now expand upon this point in the following way. The meaning of particular events in your life and of your life as a whole depends on that which individuates you as the finite being that you are; such individuation essentially includes your own death; and how you choose to live in the light of the realization of your own "being-toward-death," including how you mentally prepare yourself for death, 
determines how well or poorly equipped you are to approach death rationally and authentically.

Heidegger's conception of "authentic being-toward-death," however, is radically defective and deficient. He contrasts the public and inauthentic de-individualizing and depersonalizing of death, whereby we all think "one dies" or "everyone dies," with the authentic awareness of one's own death as one's "ownmost possibility." 80 But he also asserts that this "ownmost possibility" is "nonrelational," by which he means that all your relations to others have no place in it. ${ }^{81}$ Your experience of the deaths of others, as well as your relations to others as you face and undergo your own death, are absent from what Heidegger nonetheless calls "the full existential and ontological concept of death." 82 As a result of making one's own self primary and one's relations to others secondary, Heidegger distorts the human experience of death by severing its links to grief and love. (Being and Time says nothing about grief and love.)

I do not deny that one's own death is one's "ownmost possiblity." I deny that it is "nonrelational." Death is relational because it is interpersonal and intersubjective. Chung illustrates the point in the concluding words of his essay, "Is Dying a Transformtive Experience?"

I'm not the only one this illness has transformed. It has turned my wife into someone whose husband is dying. And it will eventually turn my wife into a widow. I do not and cannot know what it's like to watch your husband or wife suffer through this illness, and I will not know and cannot know what it's like to lose the love of my life. I can only imagine what it's like for her now and what it will be like for her then, and she can only imagine what it's like for me - and we both know that such imaginings can only give us the barest outline of what our experiences are like. There are two of us transformed by this illness, but in different ways. My wife and I are both left a little alone by this illness, left incompletely understood, even by each other.

But despite that, we are here for each other. And even if none of my friends and family really understand what it's like to be dying or what it's like to have a husband who's dying, they are here for us - unwavering and 
stalwart. Now that life seems so fragile and short to me, all this seems like a wonder. $^{83}$

A better perspective than Heidegger's on authentic being-toward-death, one that keeps death, grief, and love together, comes from the early Indian Buddhist story known as "Kisā Gotamī and the Mustard Seed." 84 The story is found in a commentary on a poem from the Therīgāthā, a collection of short poems in the Pāli language by and about the first Buddhist women. ${ }^{85}$ These women were called "therī," elders, because they were the senior, ordained, female monastics. The gāth $\bar{a}$, verses, are their poems.

Our poem is said to be chanted by Kisā Gotamī. The contemporary American poet, Anne Waldman, renders the poem as follows:

Excellent to have wise, noble friends

One should know a few things

It helps your pain

But one should understand how pain arises

how it ceases

(the Eightfold Path, the Four Noble Truths)

Mark the sorrow, mark how it comes

Being a woman is painful

Miserable sharing a home with hostile wives

Some cut their own throats

More squeamish women take poison

$\cdots$

But I survived

quenched desire

Saw the teaching as a mirror

held up to show me my crazy mind

Now healed

The poison darts extracted from my heart

All this done

and done by me 


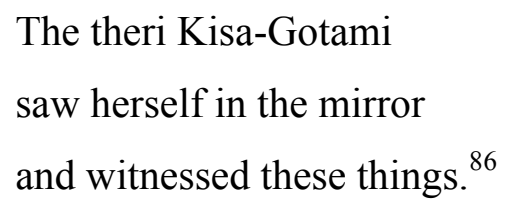

The commentary on this poem tells Kisā Gotamī's story. She is born into a poor family and named Gotamī but called "Kisā" ("lean" or "emaciated") because she is so thin. She has the good fortune to marry into a wealthy family, but she receives no respect and is badly treated until she gives birth to a son. Her happiness and good fortune, however, are short lived, for her son dies when he becomes old enough to run around and play. Mad with grief and having lost her family status, she refuses to part with her child's body and wanders everywhere, carrying the body on her hip, searching for medicine to bring him back to life. Everywhere she goes she is mocked and driven away. Finally, a kind man takes pity on her and directs her to the Buddha. She begs the Buddha for medicine to revive her son and he tells her to fetch a mustard seed from a house in which no one has died. She goes from house to house, searching frantically, but everywhere she goes she cannot find a single house in which no one has died. (This is the origin of the aphorism, "The living are few, but the dead are many," which Paul Carus used in his 1894 rendition of the story. ${ }^{87}$ Eventually it dawns on Kisā Gotamī that death is inevitable and common to all, and that everyone experiences grief when loved ones die. She lays her son's body to rest in the charnel ground, and speaks this verse:

No village law is this, no city law,

No law for this clan, or that alone;

For the whole world - and for the gods too-

This is the law: All is impermanent. ${ }^{88}$

She returns to the Buddha and he asks her whether she has obtained the mustard seed. She answers that the matter of the mustard seed is finished, and the Buddha utters this verse:

A person with a mind that clings, Deranged, to sons or possessions, Is swept away by death that comes - Like mighty flood to sleeping town. ${ }^{89}$ 
She asks to be admitted to the monastic order, is ordained, and eventually becomes an arahant, a person who has attained liberation. The Buddha proclaims her the foremost of those who wear coarse robes, and this status is said to be the attainment of an aspiration and a vow that she made in a previous existence when she witnessed an earlier Buddha bestow the same status on another woman monastic. The later tradition recognizes her for being outstanding in ascetic practices. ${ }^{90}$

Many things could be said about how we today may find things in this story that resonate with our own sensibilities - the recognition of the experience of being a woman and the esteem given to the woman's voice, the rejection of mainstream patriarchy in favour of a counterculture sustained by a deeper understanding and called to a higher purpose, and the use of poetry to express personally transformative experiences of realization. In addition, I find a deep and moving insight into our being-toward-death, an insight that can help us to see the failure of Heidegger's account.

Whereas Heidegger, in his analysis of being-toward-death, moves from the anonymous public world to the individual, the Kisā Gotamī story moves from the individual to the community, and then back to the individual and a new sense of community. Heidegger takes inauthentic being-toward-death, in the form of the anonymous, public thought "one dies," and opposes it to authentic being-toward-death, described as the realization of my own death as my "ownmost, nonrelational" possibility. Our relations to others find no place in his conception of our being-toward-death. Reading Heidegger refracted through the Kisā Gotamī story reveals the deficiency of his account: love and grief make possible authentic being-toward-death, but Heidegger says nothing about them. His famous statement, "Insofar as it 'is', death is always essentially my own," $" 91$ is faulty. I agree with Simon Critchley that Heidegger's "conception of death is both false and morally pernicious" $" 92$ to the extent that it makes the deaths of others secondary to my own death. As Critchley writes, "On the contrary... death comes into our world through the deaths of others, whether as close as a parent, partner, or child or as far as the unknown victim of famine or war. The relation to death is not first and foremost my own fear for my own demise, but my sense of being undone by the experience of grief and mourning." 93 
The Kisā Gotamī story presents this truth. The story starts from the individual experience of love, loss, and grief, and moves to an empathetic understanding of grief and death as shared by all. The realization is existentially transformative: it transforms her grief, her understanding of who and what she is, and her understanding of the whole human world (as well as her understanding of all sentient beings, including gods). She has an existentially transformative insight into the finitude of sentient existence. The insight transforms her values, preferences, and emotions, so that she lets go of her former identity and community - a scorned and grieving village wife-leaving it in the charnel ground with her dead child's body, and she joins a new community, one devoted to the practice of the mindfulness of death and the quest for liberation. ${ }^{94}$

This chapter began with the thought that death is the ultimate transformative experience. Now, at the end of the chapter, we have been brought to see that there is an important sense in which death is not the only ultimate transformative experience. Although death alone may be ultimate in the sense of being final, it is not alone in being ultimate in the sense of having fundamental significance and in having the power to transform everything else. Love and grief are also ultimate transformative experiences. So, too, is liberation from the perspective of Buddhist philosophy (as well as Indian religion and philosophy in general). All provide meta-perspectives from which to view everything else in one's life.

This chapter also began with how Paul poses the problem of transformative experience, which is by arguing that you cannot grasp a personally transformative experience until you undergo it and learn how it changes you. Without experiencing dying, you cannot fully comprehend what it is like to die. There is no way to gainsay this fact. At the same time, we have also been brought to see that there may be ways to witness death that can give us insight into what it is like to die. Being a witness in this sense does not mean being a mere observer. It means being with the dying person and bearing witness to that person's experience. It means being empathetically present to the person's own unique experience of dying and experiencing the loss of this person from your own life and from the world altogether. One reason we have so little insight into the experience of death may be that our culture resists being with the dying and bearing witness to the reality of death. 
Let me end this chapter by reminding you of the question of what it might mean for us to be able to approach death rationally and authentically, and by giving the last word to Kisā Gotamī. While she is meditating, Māra, the Indian demon associated with death, tries to distract her with his terrifying presence, just as he tried to distract Siddhārtha Gautama from his meditation on the evening of his awakening when he became the Buddha. Māra sings to Kisā Gotamī this verse:

Why are you, having lost your child,

Weeping and with sad and worried face

sitting alone under a tree?

Are you searching for a man?

Kisā Gotamī answers back:

"Without limit are the sons,

who all have died and been lost.

This, then, is the end of men [for me].

I have gone beyond [the attraction of] men's external appearance.

Not troubled, not sad or worried,

I have done what should be done in the Buddha's dispensation.

Separated from all craving and dukkha,

having entirely relinquished the darkness [of ignorance],

I have realized cessation,

I dwell in peace and at ease with influxes eradicated.

I recognize you, evil Māra,

now make yourself disappear and go! ${ }^{95}$

Māra, sad, afflicted, and annoyed, thinks, "Kisā Gotamī knows me and my intentions," and vanishes.

\footnotetext{
${ }^{1}$ I wish to thank The Experience Project (the-experience-project.org) and the Templeton Foundation for a Fellowship that supported the writing of this chapter. For helpful comments, I wish to thank Bhikkhu Anālayo, Anthony Bruno, Richard Jaffe, Troy Jollimore, Enoch Lambert, Jelena Markovic (whose research assistance was also
} 
invaluable), Laurie Paul, Geoffrey Sayre-McCord, Robert Sharf, John Schwenkler, Sean Smith, Jenny Windt, and the graduate students in my 2017 seminar on transformative experience and the philosophy of death: Katherine Cheng, Kyle Da Silva, Jasper Heaton, Andrew Jones, Matthew Kinakin, Jason Leslie, Phyllis Pearson, Matthew Smithdeal, Richard $\mathrm{Wu}$, and Steven Zhao. This chapter derives from papers presented at the American Philosophical Association Pacific Division Pre-Conference, "Themes in Transformative Experience," April 11, 2017; the Philosophy Graduate Conference at the University of Toronto, May 8-9, 2017; and The Chapel Hill Workshop on Transformative Experience, May 11, 2017.

${ }^{2}$ L. A. Paul, Transformative Experience (New York: Oxford University Press, 2014), p. 111, n. 6 .

${ }^{3}$ R. S. Morison, “Death: Process or Event?” Science 173 (1971): 694-8.

${ }^{4}$ The terms "epistemically transformative" and "personally transformative" come from Paul, Transformative Experience.

${ }^{5}$ Ibid., p. 111, n. 6 .

${ }^{6}$ Namely, reflecting the norms of WEIRD (Western, Educated, Industrialized, Rich, and Democratic) societies. See Joseph Henrich, Steven J. Heine, and Ara Norenzayan, "The Weirdest People in the World?" Behavioral and Brain Sciences 33 (2010): 61-135.

${ }^{7}$ For important elaboration and clarification of the concept of subjective value, see L. A. Paul, "Transformative Choice: Discussion and Replies," Res Philosophica 92 (2015): 473-545, especially pp. 477-479 and 500-503.

${ }^{8}$ For a powerful and moving statement of one person's reflective choice to take her own life, see Gillian Bennett, "Goodbye \& Good Luck!" at http://www.deadatnoon.com/index.html

${ }^{9}$ For philosophical discussions of the apparent impossibility of grasping death from within, see Thomas Nagel, The View from Nowhere (New York: Oxford University Press, 1986), pp. 223-231, and J. J. Valberg, Dream, Death, and the Self(Princeton, NJ:

Princeton University Press, 2007), Part Two: Death. 
${ }^{10}$ See Pierre Hadot, Philosophy as a Way of Life: Spiritual Exercises from Socrates to

Foucault, edited and with an Introduction by Arnold Davidson (Malden, MA: Blackwell

Publishing Ltd, 1995).

${ }^{11}$ I am grateful to Troy Jollimore for raising these concerns.

${ }^{12}$ See Ian Hacking, "The Looping Effects of Human Kinds," in Causal Cognition: A Multidisciplinary Debate, eds. Dan Sperber, David Premack, and Ann James Premack (New York: Oxford University Press, 1996), pp. 351-383.

${ }^{13}$ See Elizabeth Harman, "Transformative Experiences and Reliance on Moral Testimony," Res Philosophica 92 (2015): 323-329.

${ }^{14}$ See John Campbell, "L. A. Paul's Transformative Experience," Philosophy and Phenomenological Research XCI (2015): 787-793; and L. A. Paul, “Transformative Experience: Replies to Pettigrew, Barnes and Campbell," Philosophy and Phenomenological Research XCI (2015): 794-813, at pp. 806-813. See also Paul, “Transformative Choice: Discussion and Replies," p. 478.

${ }^{15}$ See Caitlin Doughty, "The Sacred Task of Caring for the Dead Should Be a Normal Part of Life," The Guardian, 13 April 2015, and Jessica Nutik Zitter, "First, Sex Ed. Then Death Ed," New York Times, February 18, 2017.

${ }^{16}$ Haider Warraich, Modern Death: How Medicine Changed the End of Life (New York: St. Martin's Press, 2017), p. 40.

${ }^{17}$ Elizabeth Barnes, "Social Identities and Transformative Experience," Res Philosophica 92 (2015): 171-187.

${ }^{18}$ Warraich, Modern Death, p. 9.

${ }^{19}$ These definitions and medical standards and criteria are also inseparable from political and practical considerations about organ donation and transplanation. See Michael NairCollins, "Taking Science Seriously in the Debate on Death and Organ Transplantation," Hastings Center Report 45 (2015): 38-48.

${ }^{20}$ Steven Luper, "Death," The Stanford Encyclopedia of Philosophy (Summer 2016 edition). https://plato.stanford.edu/archives/sum2016/entries/death/

${ }^{21}$ Ibid. 
${ }^{22}$ See David DeGrazia, "The Definition of Death," The Stanford Encyclopedia of Philosophy (Spring 2017 edition).

https://plato.stanford.edu/archives/spr2017/entries/death-definition

${ }^{23}$ Luper, "Death."

${ }^{24}$ Steven Laureys, "Death, Unconsciousness, and the Brain," Nature Reviews Neuroscience 6 (2005): 899-909, at p. 900.

${ }^{25}$ Allan Kellehear, The Inner Life of the Dying Person (New York: Columbia University Press, 2014).

${ }^{26}$ Ibid., p. 195.

${ }^{27}$ Not Nurse Ratched, "Why do we call it 'actively dying?" April 21, 2016. http://notratched.net/nnr/2016/4/21/why-do-we-call-it-actively-dying ${ }^{28}$ Warraich, Modern Death, p. 9.

${ }^{29}$ Jimo Borjigin, UnCheol Lee, Tiecheng Liu, Dinesh Pal, Sean Huff, Daniel Klarr, Jennifer Sloboda, Jason Hernandez, Michael M. Wang, and George A. Mashour, "Surge of Neurophysiological Coherence and Connectivity in the Dying Brain," Proceedings of the National Academy of Sciences USA 110 (2013): 14432-14337.

${ }^{30}$ Loretta Norton, Raechelle M. Gibson, Tenneille Gofton, and Carolyn Benson, "Electroencephalographic Recordings During Withdrawal of Life-Sustaining Therapy Until 20 Minutes After Declaration of Death," Canadian Journal of Neurological Sciences 44 (2017): 139-145.

${ }^{31}$ Daniel Kroeger, Bogdan Florea, and Florin Amzica, "Human Brain Activity Patterns Beyond the Isoelectric Line of Extreme Deep Coma," PLOS One 8 (2013): e75257. ${ }^{32}$ Kellehear, The Inner Life of the Dying Person, p. 195.

${ }^{33}$ For further discussion, see Evan Thompson, Waking, Dreaming, Being: Self and Consciousness in Neuroscience, Meditation, and Philosophy (New York: Columbia University Press, 2015), pp. 302-303.

${ }^{34}$ Sam Parnia, "Death and Consciousness-An Overview of the Mental and Cognitive Experience of Death," New York Academy of Sciences 1330 (2014): 75-93, at p. 76. ${ }^{35}$ Ibid. 
${ }^{36}$ See, for example, Hospice Patients Alliance, "Signs and Symptoms of Approaching Death," http://www.hospicepatients.org/hospic60.html

${ }^{37}$ See Thompson, Waking, Dreaming, Being, chapter 9.

${ }^{38}$ See James Warren, Facing Death: Epicurus and His Critics (Oxford: Oxford University Press, 2004).

${ }^{39}$ For example, Paul Edwards, "Existentialism and Death: A Survey of Some Confusions and Absurdities," in Sidney Morgenbesser, Patrick Suppes, and Morton White, eds., Philosophy, Science and Method: Essays in Honor of Ernest Nagel (New York: St. Martins Press, 1969), pp. 473-505.

${ }^{40}$ I draw here mainly from Kellehear, The Inner Life of the Dying Person. See also Kathleen Dowling Singh, The Grace in Dying (New York: HarperCollins, 1998) and David Kuhl, M. D., What Dying People Want (Anchor Canada, 2002).

${ }^{41}$ William Yang, Ton Staps, and Ellen Hijmans, "Existential Crisis and the Awareness of Dying: The Role of Meaning and Spirituality," Omega 61 (2010): 53-69.

${ }^{42}$ Ken Chung, "Is Dying a Transformative Experience?", August 23, 2017, at http://professorkenchung.wordpress.com/2017/08/23/is-dying-a-transformativeexperience/

${ }^{43}$ Ibid.

${ }^{44}$ See also Havi Carel, Ian James Kidd, and Richard Pettigrew, "Illness as Transformative Experience,” The Lancet 388 (2016): 1152-1153.

${ }^{45}$ See Paul, Transformative Experience. See also L. A. Paul, "What You Can't Expect When You're Expecting," Res Philosophica 92 (2015): 1-23.

${ }^{46}$ Amber D. Carpenter, "Metaphysical Suffering, Metaphysics as Therapy," in Bev Hogue and Anna Sugiyama, eds., Making Sense of Suffering: Theory, Practice, Representation (Oxford, United Kingdom: Inter-Disciplinary Press, 2011), pp. 3-10. Published as an e-book: http://www.inter-disciplinary.net/wpcontent/uploads/2011/04/msosufferingever11204111.pdf. I thank Jelena Markovic for bringing this paper to my attention, and I am indebted to her use of it in Jelena Markovic, "How to Die Before You Die: The Transformative Power of Meditation," presented at 
"Crossing Over: An Interdisciplinary Conference on Death and Morbidity," York University, Toronto, February 17-18, 2017.

${ }^{47}$ Carpenter, "Metaphysical Suffering, Metaphysics as Therapy," p. 4.

${ }^{48}$ Susan J. Brison, Aftermath: Violence and the Remaking of a Self (Princeton, NJ:

Princeton University Press, 2002), p. 73.

${ }^{49}$ Ibid., p. 39.

${ }^{50}$ Ibid., pp. 39-40.

${ }^{51}$ Ibid., p. 60.

${ }^{52}$ Ibid.

${ }^{53}$ Ibid., p. 8.

${ }^{54}$ Ibid., pp. 8-9.

${ }^{55}$ Ibid., p. 21.

${ }^{56}$ Ibid., p. 54.

${ }^{57}$ Ibid.

${ }^{58}$ Maxxine Rattner and Joan Berzoff, "Rethinking Suffering: Allowing for Suffering That Is Intrinsic at End of Life," Journal of Social Work in End-of-Life \& Palliative Care 12 (2016): 240-258.

${ }^{59}$ Ibid. See also Joan Halifax, Being with Dying: Cultivating Compassion and Fearlessness in the Face of Death (Boston, MA: Shambhala Publications, 2008).

${ }^{60}$ Brison, Aftermath, pp. 103, 115.

${ }^{61}$ Yang et al., "Existential Crisis and the Awareness of Dying," p. 60.

${ }^{62}$ Ibid., p. 63.

${ }^{63}$ R. N. Butler, "The Life Review: An Interpretation of Reminiscence in the Aged," Psychiatry 26 (1963): 65-76; Kellehear, The Inner Life of the Dying Person, pp. 149-167. ${ }^{64}$ Ibid., p. 159.

${ }^{65}$ Thomas DeBaggio, Losing My Mind: An Intimate Look at Life with Alzheimer's (New York: Free Press, 2002), p. 113, as quoted by Kellehear, The Inner Life of the Dying Person, p. 153.

${ }^{66}$ Bruce Greyson, "The Near-Death Experience Scale: Construction, Reliability, and Validity," Journal of Nervous and Mental Disease 71 (1983): 369-375. 
${ }^{67}$ Kellehear, The Inner Life of the Dying Person, p. 191.

68 Ibid., p. 205.

${ }^{69}$ Ibid., p. 194.

${ }^{70}$ Ibid., p. 200.

${ }^{71}$ C. W. Kerr, J. P. Donnelly, J. P. Wright, S. M. Kuszcack, A. Banas, P. C. Grant, and D.

L. Luczkiewicz, "End of Life Dreams and Visions: A Longitudinal Study of Hospice Patients' Experiences," Journal of Palliative Medicine 17 (2014): 296-303.

${ }^{72}$ Kellehear, The Inner Life of the Dying Person, pp. 196-197.

${ }^{73}$ L. A. Paul, Transformative Experience.

${ }^{74}$ Carel et al., "Illness as Transformative Experience," use the term "existentially transformative" to describe illness experience.

75 Jean-Paul Sartre, Being and Nothingness, translated by Hazel E. Barnes (New York: Washington Square Press, 1956), p. 698. I have slightly modified Barnes's translation, using "possibility" instead of her "possible." The French reads: "Etre fini, en effet, c'est se choisir, c'est-à-dire se faire annoncer ce qu'on est en se projetant vers un possible, à l'exclusion des autres." Jean-Paul Sartre, L'être et le néant. Essai d'ontologie phénoménologique (Paris: Éditions Gallimard, 1943), p. 591.

${ }^{76}$ Sartre, Being and Nothingness, p. 698.

${ }^{77}$ Bernard Williams, "The Makropolous Case: Reflections on the Tedium of Immortality," in Bernard Williams, Problems of the Self (Cambridge: Cambridge University Press, 1973), pp. 82-100.

${ }^{78}$ Paul, Transformative Experience, pp. 1-4.

${ }^{79}$ Martin Heidegger, Being and Time, trans. Joan Stambaugh (Albany, NY: State University of New York Press, 2010), §§46-53.

${ }^{80}$ To my mind, Tolstoy, in The Death of Ivan Ilyich, depicts this contrast better and more vividly. See Leo Tolstoy, The Death of Ivan Ilyich, trans. Anthony Briggs (London:

Penguin, 2006).

${ }^{81}$ Heidegger, Being and Time, p. 239.

82 Ibid.

${ }^{83}$ Chung, "Is Dying a Transformative Experience?" 
${ }^{84}$ See "Kisā Gotami," in Robert E. Buswell, Jr. and Donald S. Lopez, Jr, eds., The Princeton Dictionary of Buddhism (Princeton, NJ: Princeton University Press, 2914), p. 437.

${ }^{85}$ Charles Hallisey, trans., Therigatha: Poems of the First Buddhist Women (Cambridge, MA: Harvard University Press, 2015),

${ }^{86}$ Andrew Shelling and Anne Waldman, trans., Songs of the Sons and Daughters of Buddha (Boston and London: Shambhala Publications, 1996), pp. 69-70. For a more scholarly translation, see Hallisey, trans., Therigatha, pp. 110-115.

${ }^{87}$ Paul Carus, The Gospel of the Buddha (Chicago and London: Open Court Publishing, 1915), pp. 209-213.

${ }^{88}$ I use the translation from "Inspiration from Enlightened Nuns," by Susan Elbaum Jootla, retrieved from http://www.accesstoinsight.org/lib/authors/jootla/wheel349.html ${ }^{89}$ I use here Andrew Oldenzki's translation, "Skinny Gotami and the Mustard Seed," retrieved from http://www.accesstoinsight.org/noncanon/comy/thiga-10-01-ao0.html ${ }^{90}$ See Bhikkhu Anālayo, "Outstanding Bhikkhun̄̄s in the Ekottarika-āgama," in A. Collet, ed., Women in Early Buddhism: Comparative Textual Studies (New York: Oxford University Press, 2014), pp. 97-115.

${ }^{91}$ Heidegger, Being and Time, p. 223.

${ }^{92}$ Simon Critchley, "Being and Time: part 6," The Guardian, Monday 13 July 2009. ${ }^{93}$ Ibid.

${ }^{94}$ For translations of the early scriptural presentations of the mindfulness of death, see Anālayo, Mindfully Facing Disease and Death: Compassionate Advice from Early Buddhist Texts (Cambridge, UK: Windhorse Press, 2016).

${ }^{95}$ See Bhikkhu Anālayo, "Deying Māra—Bhikkhun̄̄’s in the Samyukta-āgama," in A. Collett, ed., Women in Early Buddhism: Comparative Textual Studies (New York: Oxford University Press, 2014), pp. 116-139, at pp. 123-124. 